\title{
PEMAKNAAN KEMBALI EKSISTENSI AKUNTANSI SYARIAH: KAJIAN EPISTEMOLOGI
}

\author{
Agus Munandar', Dini Marina ${ }^{2}$ \\ Program Studi Akuntansi, Fakultas Binis, Institut Teknologi dan Bisnis Kalbis ${ }^{1}$; Program \\ Studi Akuntansi, Fakultas Ekonomi dan Bisnis, Universitas Indonesia ${ }^{2}$ \\ agus.munandar@kalbis.ac.id
}

\begin{abstract}
The Purpose of this study is to perform reinterpretation existence of sharia accounting based on epistemology approach. Based on diversed opinions whether accounting is science or art, this article stated that sharia accounting is science. This statement proved using the conceptual framework developed some islamic scholars and philosopher such as truth theory and espitemology approach. Finally, this article proposes that sharia accounting have some legitimacy as a subject of study.
\end{abstract}

Keywords: legitimacy, science, sharia accounting

\section{PENDAHULUAN}

Pertanyaan mengenai pengkategorian akuntansi sebagi ilmu masih menjadi perdebatan antar pakar ilmu pengetahuan. Sebagian menyatakan bahwa akuntansi penuh dengan subjektifitas (value laden) sehingga terlepas dari ilmu. Di lain sisi, para pakar berpendapat bahwa akuntansi dikembangkan sesuai dengan metode positivis yang berusaha mengungkap kebenaran hakiki.

Merujuk pada pendapat Nelson (1949) yang mengutip publikasi LaSalle Extension University bahwa akuntansi merupakan sains yang bertujuan untuk menyajikan fakta bisnis secara sistematis dan memiliki aturan yang dirancang untuk mengatur pencatatan fakta bisnis. Kebimbangan pengakategorian telah dialami oleh Kester (1917) ketika menjawab pertanyaan apakah akuntansi seni atau sains, Kester menjawab bahwa terdapat seni dan sains di akuntansi.

Kehadiran akuntansi syariah sebagai alternatif atas akuntansi yang berpandangan sekuler yaitu memisahkannya dari agama dan nilai religiusitas (Moerman, 2006). Berdasarkan perspektif luas, akuntansi tidak terbatas pada nilai sekuler dan materialis yang memisahkan kehidupan manusia (human life) dan realitas (reality). Untuk itu, akuntansi diperlakukan sebagai instrumen untuk mengarahkan kehidupan manusia agar mencapai tujuan utama yaitu kebahagiaan dunia akhirat (Triyuwono, 2013). Untuk itu, secara normatif, akuntansi syariah terkonseptualisasi berdasarkan ajaran islam (islamic tenets) yang memberikan kebahagiaan bagi pemeluknya baik di dunia maupun di akhirat. Akuntansi Syariah merupakan salah satu alternatif akuntansi yang didasarkan pada pendekatan teologi islam (Gallhofer and Haslam, 2004). 
Studi ini bertujuan untuk mengkaji kembali makna eksistensi akuntansi syariah menggunakan pendekatan epistemologi. Kajian atas keabsahan akuntansi syariah sebagai ilmu menggunakan metode (pendekatan) teori kebenaran (the theory of thruth) yang dikemukakan oleh para sarjana muslim (ulama) seperti teori kebenaran bayani, irfani, dan burhani dan teori para filsuf barat seperti teori korespondensi yang dikembangkan oleh Bertand Russel (1872-1970), teori koherensi, dan teori pragmatis.

\section{Pendekatan Para Sarjana Muslim}

Keabsahan pengetahuan adalah tatkala pemahamannya mendekati, menyerupai, dan setara dengan fakta atau kenyataan (wujud). Validasi merupakan proses konformitas pengetahuan atas fakta (tasdiq/ certification of truth). Kesenjangan antara pengetahuan dan fakta menimbukan keraguan atas kebenaran yang tingkatannya sebagaimana berikut,

a. Jahil basit, yaitu individu yang tidak memiliki pengetahuan tentang kebenaran sama sekali.

b. Jahil murakkab, yaitu individu yang menggangap dirinya mengetahui kebenaran padahal pengetahuannya berbeda dengan fakta (realita).

c. Syak, yaitu individu yang ragu atas pengetahuannya.

d. Zan, yaitu sesoerang memiliki pengetahuan atas kebenaran tetapi masih memiliki keraguan bahwa pengetahuannya keliru.

e. Waham, pribadi yang memiliki pengetahuan yang keliru tetapi berusaha memperoleh pengetahuan yang benar.

Di kajian epistemologi Barat, terdapat tiga aliran pemikiran tentang kebenaran yaitu empirisme, rasionalisme dan intuitisme. Sementara itu, dalam kajian pemikiran Islam terdapat bayâni, irfâni, dan burhâni yang memiliki persepsi kebenaran secara masing-masing. Perbandingan antar persepsi terkait kebenaran sebagaimana tabel berikut.

Tabel 1. Komparasi Kebenaran Pengetahuan

\begin{tabular}{llll}
\hline & Bayani & Irfani & Burhani \\
\hline Sumber & Teks Keagamaan & Ilham & Rasio \\
Metode & Istinbat & Istidlal & Tahlili \\
Validitas Kebenaran & Korespondensi & Intersubjektif & Koherensi \\
\hline
\end{tabular}




\section{Perspektif Bayani}

Pendekatan bayani merupakan pemikiran yang menekankan pada otoritas teks (nash) baik secara langsung atau tidak langsung, dan divalidasi keabsahannya melalui pemikiran inferensial (istidlal). Berfikir menggunakan pendekatan bayani langsung memaknai bahwa teks merupakan pengetahuan akhir sehingga tanpa pemaknaan rasio. Adapun pemaknaan tak langsung yaitu melibatkan kajian rasio atas teks.

Menurut Al-Jabiri, penalaran bayani merupakan sistem berpikir yang mendasarkan bahasa Arab sebagai titik tolak penalaran dan qiyas (analogi) sebagai metode penalaran. Karakteristik pemikiran ini adalah ketergantungannya pada teks yaitu al-Qur'an dan Sunnah.

Berbasis pendekatan epistemologi bayani, akuntansi syariah merupakan ilmu yang dikembangkan melalui penalaran logis berdasarkan petunjuk Alloh. Hal ini sesuai dengan pernyataan Ibnu Sina bahwa logika merupakan kunci utama untuk pengetahuan dan tidak dapat tergantikan kecuali dengan petunjuk Alloh.

Berdasarkan teks Al-Quran dan Sunnah telah menjelaskan bahwa pencatatan bisnis yang islami telah disyiratkan dalam berbagai teks seperti dalam QS. Al Baqoroh ayat 282 sebagaimana berikut,

"Hai orang-orang yang beriman, apabila kamu bermu'amalah tidak secara tunai untuk waktu yang ditentukan, hendaklah kamu menuliskannya. dan hendaklah seorang penulis di antara kamu menuliskannya dengan benar. dan janganlah penulis enggan menuliskannya sebagaimana Allah mengajarkannya, meka hendaklah ia menulis, dan hendaklah orang yang berhutang itu mengimlakkan (apa yang akan ditulis itu), dan hendaklah ia bertakwa kepada Allah Tuhannya, dan janganlah ia mengurangi sedikitpun daripada hutangnya. jika yang berhutang itu orang yang lemah akalnya atau lemah (keadaannya) atau Dia sendiri tidak mampu mengimlakkan, Maka hendaklah walinya mengimlakkan dengan jujur. dan persaksikanlah dengan dua orang saksi dari orang-orang lelaki (di antaramu). jika tak ada dua orang lelaki, Maka (boleh) seorang lelaki dan dua orang perempuan dari saksi-saksi yang kamu ridhai, supaya jika seorang lupa Maka yang seorang mengingatkannya. janganlah saksi-saksi itu enggan (memberi keterangan) apabila mereka dipanggil; dan janganlah kaти јети теnulis hutang itu, baik kecil maupun besar sampai batas waktu membayarnya. yang demikian itu, lebih adil di sisi Allah dan lebih menguatkan persaksian dan lebih dekat kepada tidak (menimbulkan) keraguanmu. (Tulislah mu'amalahmu itu), kecuali jika mu'amalah itu perdagangan tunai yang kamu jalankan di antara kamu, Maka tidak ada dosa bagi kamu, (jika) kamu tidak menulisnya. dan persaksikanlah apabila kamu berjual beli; dan janganlah penulis dan saksi saling sulit menyulitkan. jika kamu lakukan (yang demikian), Maka Sesungguhnya hal itu adalah suatu kefasikan pada 
dirimu. dan bertakwalah kepada Allah; Allah mengajarmu; dan Allah Maha mengetahui segala sesuatu." (Al Baqoroh ayat 282)

Selain teks yang tercantum di QS Al Baqoroh tersebut, Alloh telah menjelaskan kode etik akuntan untuk senantiasa berintegritas dan menunaikan amanah secara adil sehingga akuntan merupakan perwujudan teori stewardship. Hal ini sebagaimana dijelaskan dalam QS An-Nisa ayat 58 sebagaimana berikut,

"Sesungguhnya Allah menyuruh kamu menyampaikan amanat kepada yang berhak menerimanya, dan (menyuruh kamu) apabila menetapkan hukum di antara manusia supaya kamu menetapkan dengan adil. Sesungguhnya Allah memberi pengajaran yang sebaik-baiknya kepadamu. Sesungguhnya Allah adalah Maha mendengar lagi Maha melihat". (An-Nisa ayat 58)

Di Q.S An Nisa Ayat 29, Alloh juga telah menjelaskan pelarangan berbuat curang (fraud) sehingga merugikan orang lain. Untuk itu, seorang akuntan harus mengakui aset sesuai dengan haknya. Begitupula untuk akun-akun perusahaan yang lain. Perintah untuk menjauhi fraud tersebut sebagaimana berikut,

"Hai orang-orang yang beriman, janganlah kamu saling memakan harta sesamamu dengan jalan yang batil, kecuali dengan jalan perniagaan yang Berlaku dengan suka sama-suka di antara kamu. dan janganlah kamu membunuh dirimu; Sesungguhnya Allah adalah Maha Penyayang kepadamu”.

Kehadiran akuntansi syariah (islam) sebagai alat yang memungkinkan setiap pebisnis muslim untuk mengevaluasi akuntabilitasnya terhadap Alloh terkait hubungan antar manusia dan hubungan dengan lingkungan (Shanmugam \& Perumal, 2005, p. 11). Untuk itu, tujuan utama akuntansi syariah adalah meraih ridho Alloh SWT (Napier, 2009).

Berdasarkan pendekatan bayani, akuntansi syariah dimaknai sebagai kebenaran dan dikategorikan sebagai pengetahuan yang valid karena berdasarkan teks yang otentik dan memiliki tingkat validitas tinggi. Kajian teks tersebut didasarkan pada al-Qur'an dan Sunnah yang merupakan sumber kebenaran hakiki.

\section{Perspektif Irfani}

Pemikiran menggunakan perspektif irfani berpendapat bahwa kebenaran merupakan hal yang didasarkan atas pendekatan atau pengalaman secara langsung atas realitas spritual.

Pola pikir para irfaniyun selalu bertolak dari pengalaman bathin yang ditujukan pada dzahir. Untuk itu, interpretasi makna berangkat dari makna yang menuju lafadz.

Menurut irfaniyun, Bathin merupakan sumber pengetahuan yang kemudian dianggap sebagai kebenaran. Berdasarkan pendekatan ini, akuntansi syariah yang berlandaskan pada ajaran Al-Quran termasuk kebenaran karena Al-Quran merupakan wahyu yang diperoleh dari pengalaman spiritual yang diturunkan oleh Alloh SWT melalui perantara malaikat Jibril. 
Kebenaran surat Al-Alaq yang merupakan surat pertama merupakan pengalaman kebenaran atas ilmu yang diturunkan kepada Rosululloh pada saat Beliau tahannuts (menyendiri) di Gua Hira'. Secara ringkas, surat Al-Alaq merupakan wahyu yang disampaikan kepada Rosululloh dengan memberikan konteks spiritual yang tinggi. Karena itu, akuntansi syariah yang menyandarkan pendekatannnya pada kitab suci yang memiliki konteks pengalaman spiritual yang tinggi dikategorikan sebagai ilmu pengetahuan yang sah dan valid.

\section{Perspektif Burhani}

Episteme burhani merupakan pendekatan pengujian validitas kebenaran menggunakan rasio (pemikiran) atas suatu fakta. Pola pendekatan ini telah disanjung oleh Ibn Rushd yang selalu mendekatakan kebenaran berbasis rasio.

Epistemologi burhani berpandangan bahwa akal (rasio) merupakan sumber ilmu pengetahuan. Akal memiliki kemampuan untuk mencapai kebenaran. Epistemologi ini sering digunakan oleh golongan berpaham rasionalis seperti Mu'tazilah dan para ulama moderat.

Pendekatan akal sebagai sumber kebenaran koheren dengan filsuf Barat yang berpaham rasionalisme seperti Rene Descartes (1596-1650), Baruch Spinoza (1632 -1677) dan Gottried Leibniz (1646-1716).

Di ilmu tafsir atas teksi diperkenankan penggunaan rasio dan akal selama tidak bertentangan dengan syariat. Lebih dari itu, penggunaan rasio sangat untuk memahami suatu hal sangat ditekankan oleh al-Quran sebagaimana dalam Surat Al-A'raf ayat 185

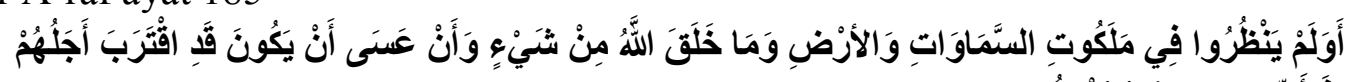

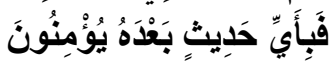

Artinya: Dan apakah mereka tidak memperhatikan kerajaan langit dan bumi dan segala sesuatu yang diciptakan Allah, dan kemungkinan telah dekatnya kebinasaan mereka? Maka kepada berita manakah lagi mereka akan beriman sesudah Al Quran itu? (QS. Al A'raf Ayat 195)

Berdasarkan argumentasi bahwa akuntansi syariah merupakan kajian yang didasarkan pada ajaran yang memberikan peluang berfikir dan ajaran yang konsisten dengan logika manusia, akuntansi syariah merupakan subjek yang ilmiah dan logis.

\section{Pendekatan Para Sarjana Barat}

Pemaknaan kebenaran telah menjadi fokus para filsuf selama berabad-abad. Perjalanan panjang ini menimbulkan keberagaman pendekatan dalam memaknai kebenaran. Sebagian berpendapat bahwa tidak mungkin untuk mencapai/ memperoleh kebenaran final. Persepsi ini dipegang oleh Gogias yang merupakan kaum sofis yang menaruh pandangan-pandangan skeptis tentang pengetahuan, tentang nilai etis, bahkan cenderung untuk menghilangkan tentang keberadaan pengetahuan yang objektif atas eksistensi apapun (Lubis, 2014). 
Pendekatan skeptisisme pengetahuan termanifestasi dalam berbagai bentuk skeptisme sebagaimana berikut,

1. Solipsisme

2. Skeptisime Sensoris

3. Skeptisisme Rasional

4. Skeptisisme Metodologis

Lubis (2014) menjelaskan bahwa solipsisme merupakan pandangan bahwa saya hanya mengetahui diri saya dan tidak mengetahui di luar saya. Skeptisme sensoris dimaknai bahwa sensori bersifat tidak reliabel. Skeptisisme rasional merupakan pendapat tentang keraguan yang disebabkan oleh paradoks atau antinomi. Terakhir, skepstisisme metodologis berpendapat bahwa keraguan bersifat sistematis dan semesntara yang bertujuan untuk menemukan pengetahuan yang kuat dan dipercaya.

Berkebalikan dengan pemahaman skeptisisme, Para filsuf seperti Aristoteles, Phytagoras, Hegel, James berpendapat bahwa kebenaran adalah ada, sesuai dengan perspektif masing-masing. Pendekatan perspektif tersebut dapat disampaikan sebagaimana berikut,

1. Teori kebenaran korespondensi

2. Teori kebenaran konsistensi

3. Teori kebenaran Pragmatis

Ketiga pandangan tersebut memberikan pendekatan yang berbeda dalam hal penafsiran validitas pengetahuan/ keabsahan ilmu.

\section{Teori Kebenaran Korespondensi (Correspondence Theory of Truth)}

Aristoteles berpendapat bahwa kebenaran adalah kesetiaan terhadap realitas objektif. Untuk itu, kebenaran dinyatakan dengan ungkapan veritas est adaequatio intellectus et rhei yang berarti bahwa kebenaran adalah persamaan sesuatu dengan pengetahuan (Truth is the equation [or adequation] of things and intellect). Teori ini dikenal dengan teori cermin atau teori kebenaran korespondensi. Teori korespondensi dianut oleh para pengikut realisme seperti Plato, Aristoteles, Ramsey, dan Moore. Teori korespodensi pertama kali dikembangkan oleh Bertrand Russell.

Berdasarkan pendekatan korespondensi, berbagai ayat Al Quran telah menjelaskan fakta yang sesuai dengan kenyataan sebagaimana pernyataan tentang pertemuan antara air asin dan air tawar tanpa bercampur baur.

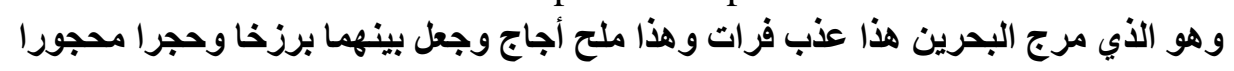

Terjemah:

Dan dialah yang membiarkan dua laut yang mengalir (berdampingan); yang Ini tawar lagi segar dan yang lain asin lagi pahit; dan dia jadikan antara keduanya dinding dan batas yang menghalangi”. (QS Al-Furqan : 53) 
Pernyataan tersebut terbukti dengan fakta di selat gibraltar yang merupakan pertemuan dua lautan yang tidak bercampur. Selat tersebut memisahkan benua Afrika dan Eropa, tepatnya memisahkan negara Maroko dan Spanyol. Pemisahan asin dan tawar di selat Gribraltar disebabkan perbedaan masa jenis. Untuk itu, kedua air dari kedua lautan tersebut tidak becampur sehingga seperti terdapat dinding tipis yang memisahkannya.

Berdasarkan argumentasi tersebut maka akuntansi syariah yang didasarkan pada kitab suci memiliki kebenaran korespondensi. Untuk itu, akuntansi syariah merupakan ilmu pengetahuan. Alhasil, akuntansi syariah yang bersumber pada kebenaran hakiki tersebut merupakan kebenaran yang sesuai dengan realita.

\section{Kebenaran Konsistensi (The Coherence Theory of Truth)}

Lubis (2014) menyatakan bahwa teori kebenaran ini didasarkan pada saling berhubungan antara putusan atau kesesuaian dengan kesepakatan atau pengetahuan yang dimiliki. Suatu pernyataan dianggap benar jika koheren dengan pernyataan sebelumnya. Teori kebenaran ini menggunakan perspektif penalaran deduktif.

Salah satu contoh koherensi dan konsistensi dalam al-Qur'an adalah pernyataan tentang zina:

$$
\text { و لا تقربوا الزنا إنه كان فاحشة وساء سبيلا }
$$

Artinya: "Dan janganlah kamu mendekati zina; Sesungguhnya zina itu adalah suatu perbuatan yang keji. dan suatu jalan yang buruk”. (QS.Al Israa. ayat 32)

Pernyataan tersebut koheren dan konsisten dengan pernyataan al-Qur'an yang lain seperti:

و الذين لا يدعون مع الله إلهاً آخر، ولا يقتلون النفس التي حرم الله إلا بالحق ولا يزنون ومن يفعل ذلك يلق

Artinya: "Dan orang-orang yang tidak menyembah Tuhan yang lain beserta Allah dan tidak membunuh jiwa yang diharamkan Allah (membunuhnya) kecuali dengan (alasan) yang benar, dan tidak berzina, barang siapa yang melakukan yang demikian itu, niscaya dia mendapat (pembalasan) dosa(nya)”. (QS. AlFurqan Ayat 68).

\section{Teori Kebenaran Pragmatis (The Pragmatic Theory of Truth)}

Berdasarkan pendekatan kebenaran pragmatis, sesuatu pernyataan menjadi benar jika memiliki manfaat praktis. Teori ini ditokohi oleh banyak filsuf seperti Charles Sander Pierce (1834-1914), William James (1842-1910), dan John Dewey (1859-1952) (Honderich, 1995).

Di topik akuntansi syariah terdapat berbagai ayat yang menjadi rujuan dan berdampak manfaat bagi umat manusia. Riba merupakah salah satu konsep dalam 
akuntansi syariah yang memberikan dampak signifikan dalam kehidupan berbisnis. Dalam surat Ali Imran Allah Subhanahu wa ta'ala berfirman:

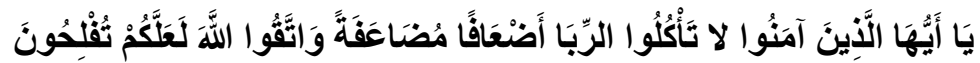

Artinya: "Hai orang-orang yang beriman, janganlah kamu memakan Riba dengan berlipat ganda dan bertakwalah kamu kepada Allah supaya kamu mendapat keberuntungan.” (QS. Ali Imraan: 130)

Shafique et al. (2012) menjelaskan bahwa krisis keuangan berdampak minor atas lembaga keuangan islami sebagaimana pernyataannya berikut,

So it is proved from all reports, past records, famous authors and experts views that there is a less impact of global financial crises on Islamic banking system which is an integral part of the Islamic finance as compared to conventional banks.

Berdasarkan pendekatan pragmatis atau kebermanfaatan pernyataan duni praktik nyata tersebut maka akuntansi syariah merupakan pendekatan yang bermanfaat. Karena itu, akuntansi syariah dikategorikan sebagai kebenaran atau ilmu pengetahuan.

\section{Simpulan}

Kegamangan memposisikan akuntansi syariah sebagai ilmu atau seni merupakan motivasi studi ini. Menggunakan episteme yang dikembangkan oleh para sarjana muslim dan para filsuf barat, studi ini memberikan kesimpulan bahwa akuntansi syariah merupakan ilmu pengetahuan.

Posisi akuntansi syariah sebagai ilmu pengetahuan didasarkan pada penyandaran konsep dan aturan praktik terhadap suatu kitab suci yang memiliki kebenaran irfani, burhani, bayani, korespondensi, koherensi, dan pragmatis.

Berdasarkan fakta tersebut maka akuntansi syariah merupakan ilmu pengetahuan yang berkonsep jelas dan sesuai dengan fakta, logika, dan pengalaman spiritual.

\section{REFERENSI}

Al Jabiri, Muhammad Abed (1989), Formasi Nalar Arab (Takwin al 'Aql al Arabi) alih bahasa Imam Khoiri, Yogyakarta

Gallhofer, S dan Haslam, J (2004) "Accounting and liberation theology: Some insights for the project of emancipatory accounting", Accounting, Auditing \& Accountability Journal, 17 (3), 382-407

Honderich, Ted (1995). The Oxford Companion to Phylosophy. Oxford, New York: Oxford Univeristy Press

Ibn Sina (980-1037) al-Isharat wa'l-tanbihat (Remarks and Admonitions), part translated by S.C. Inati, Remarks and Admonitions: Part One, Logic, 
Toronto: Pontifical Institute for Mediaeval Studies, 1984. (The most comprehensive of Ibn Sina's logic and best representation of Arabic logic.)

Lubis, A.Y.. (2014) Filsafat Ilmu; Klasik Hingga Kontemporer,. (Jakarta: Rajawali Pers

Nelson, E. (1949). Science and Accounting. The Accounting Review, 24(4), 354359. Retrieved from http://www.jstor.org/stable/239799

Roy B. Kester (1917) Accounting Theory and Practice, 1917, p. v.

Shafique, Azam; Faheem, M.A; Abdullah, I. (2012) Impact of Global Financial Crises on the Islamic Banking SystemAnalysis of Islamic Financial System during Financial Crunch 2008. Arabian Journal of Business and Management Review (OMAN Chapter) Vol. 1, No.9

Triyuwono, I. (2013). So, What is Sharia Accounting? IMANESI, 1(1), 42-5 